Brazilian Journal

of Chemical

Engineering

ISSN 0104-6632

Printed in Brazil

www.abeq.org.br/bjche

Vol. 36, No. 01, pp. 143 - 156, January - March, 2019

dx.doi.org/10.1590/0104-6632.20190361s20170643

\title{
DILUTE ACID HYDROLYSIS OF SWEET SORGHUM BAGASSE AND FERMENTABILITY OF THE HEMICELLULOSIC HYDROLYSATE
}

\author{
Danille Camargo ${ }^{1 *}$, Eduardo B. Sydney ${ }^{1}$, Lillian V. Leonel ${ }^{2}$, \\ Tania C. Pintro ${ }^{2}$ and Luciane Sene ${ }^{2}$

\begin{abstract}
${ }^{1}$ Universidade Tecnológica Federal do Paraná, Departamento de Engenharia de Bioprocessos e Biotecnologia, Toledo/PR, Brasil. E-mail: daniellecamargo@utfpr.edu.br, ORCID: 0000-0003-3124-4676; ORCID: 0000-0001-7194-8315

${ }^{2}$ Universidade Estadual do Oeste do Paraná, Centro de Ciências Exatas e Tecnológicas, Cascavel/PR, Brasil. ORCID: 0000-0002-9913-4652; ORCID: 0000-0003-0796-4366; ORCID: 0000-0002-8649-7323
\end{abstract}

(Submitted: December 12, 2017 ; Revised: May 23, 2018 ; Accepted: August 26, 2018)

\begin{abstract}
This study aimed to determine the best dilute acid hydrolysis condition for the hemicellulosic fraction of sweet sorghum bagasse for ethanol production by Scheffersomyces stipitis. The experiment followed a $2^{3}$ factorial design with four central points, and had as variables: sulfuric acid concentration, temperature and hydrolysis time. Sorghum bagasse presented the following chemical composition: $24.77 \%$ of lignin, $31.28 \%$ of hemicellulose and $34.80 \%$ of cellulose. The hydrolysis that resulted in the highest sugars concentration (14.22 g/L of xylose and $2.42 \mathrm{~g} / \mathrm{L}$ glucose) was $1.75 \% \mathrm{H}_{2} \mathrm{SO}_{4}, 121{ }^{\circ} \mathrm{C}$ and 40 minutes. This same condition provided low concentrations of toxic compounds $(1.34 \mathrm{~g} / \mathrm{L}$ of acetic acid, $0.90 \mathrm{~g} / \mathrm{L}$ of phenol; $124.54 \mathrm{mg} / \mathrm{L}$ of hydroxymethylfurfural (HMF) and $978 \mathrm{mg} / \mathrm{L}$ of furfural). The fermentation of the hemicellulose-derived sugars by S. stiptis resulted in $22 \mathrm{~g} / \mathrm{L}$ of ethanol, $\mathrm{Y}_{\mathrm{P} / \mathrm{S}} 0.40 \mathrm{~g} / \mathrm{g}$ and Qp $0.34 \mathrm{~g} / \mathrm{L} . \mathrm{h}$.

Keywords: Fermentation; Hemicellulose; Bioethanol; Scheffersomyces stipitis.
\end{abstract}

\section{INTRODUCTION}

Most of the chemicals currently used in our society comes from fossil sources. However, the oscilation of prices of these resources, their uncertain availability, and environmental concerns of their exploration have created a demand for alternative chemicals based on renewable sources (Cherubini and Stroman, 2011). In this sense, the use of lignocellulosic biomass to obtain commodities tends to become increasingly important in the future society, as a complement to existing oil refineries (Jönsson et al., 2013).

The greatest potential for the long-term production of ethanol is the use of cellulosic materials, which comprise crop residues, energy crops, short rotation plants and forestry wastes (Wang et al., 2012). Several studies have focused on the use of agricultural waste as a low cost raw material for conversion into fuel ethanol, such as wheat straw (Singhania et al., 2014; Saha et al., 2015), rice straw (Belal, 2013; Silva et al., 2014), corn stover (Gladis et al., 2015; Buruiana et al., 2014) and bagasse (Rabelo et al., 2014; GutiérrezRivera et al., 2014).

Lignocellulosic biomass is composed of three major structural biopolymers called cellulose, hemicellulose and lignin. Cellulose is a linear homopolymer formed from glucose subunits linked together by glycosidic bonds of the $\beta-1,4$ type, whereas hemicellulose is a heteropolymer formed from hexose and pentose sugars such as glucose, mannose, galactose, xylose and arabinose (Pérez et al., 2002; Singh et al., 2011; $\mathrm{Pu}$ et al., 2013). Another difference between cellulose and hemicellulose is that the latter has ramifications made of short side chains and, in contrast to cellulose,

\footnotetext{
* Corresponding author: Danille Camargo - E-mail: daniellecamargo@utfpr.edu.br
} 
the polymers are more readily hydrolysable (Pérez et al., 2002). Lignin, in turn, is an aromatic polymer synthesized from phenylpropanoid precursors (guaiacyl, syringyl and p-hydroxyphenyl) and has high molecular weight, irregular structure and is highly insoluble and recalcitrant (Wong, 2009; Pu et al., 2013).

The process of ethanol production from lignocellulosic materials includes steps of pretreatment, hydrolysis of cellulose and hemicellulose into monomeric sugars, fermentation of sugars to ethanol, and finally, distillation and purification of ethanol (Jafari et al., 2011). During the pretreatment, the biomass is subjected to a combination of physical, thermal or chemical actions, which have the purpose of making the plant cell walls more susceptible to the following steps (Dien et al., 2009). The pre-treatment using dilute sulfuric acid has been the most widely used treatment for the separation of cell wall components with high efficiency and at low cost. This procedure results in hemicellulose hydrolysate and cellulignin (Dussán et al., 2014). This method can solubilize the hemicellulose into monomeric sugars (glucose, xylose, etc.) and soluble oligomers, thus improving the conversion of cellulose (Mehmood et al., 2009).

The cost efficiency in a biorefinery is dependent on the development of biomass pre-treatment technologies that are effective for obtaining high yields of fermentable sugars from biomass sources at a lower cost (Oh et al., 2015). In addition, the use of the different types of sugars present in the raw materials must be considered, including pentoses, such as arabinose and mainly xylose, derived from the hemicellulosic fraction of the biomass.

Some yeasts demonstrate great potential to ferment pentoses, such as yeast strains like Scheffersomyces (Pichia) stipitis, Candida shehatae and Pachysolen tannophilus (Agbogbo and Coward-Kelly, 2008). Among yeasts, S. stipitis has been shown to be industrially interesting for metabolizing xylose rapidly with high ethanol yields (Nigam, 2001) and low xylitol production (Toivola et al., 1984).

The generation of by-products such as aromatic compounds, aliphatic acids, aldehydes, furans, and inorganic ions, alcohols or other products that can act as microorganism inhibitors is strongly dependent on the feedstock and the method of pre-treatment used for the lignocellulosic biomass (Jönsson et al., 2013). These toxic compounds are produced during the hydrolysis process from the breakdown of lignocellulosic materials. Phenolic compounds are produced from the degradation of lignin (Barakat et al., 2012), while acetic acid is derived from acetyl groups present in the hemicellulose polymers that are released during the hydrolysis (Silva et al., 2013). Furfural and hydroxymethylfurfural (HMF) come from the degradation of pentoses (xylose and arabinose) and hexoses (glucose, mannose and galactose), respectively (Dagnino et al., 2013).

Currently world ethanol production is basically derived from two crops, corn and sugarcane. However, with increasing demand for food production and increased consumption of fuel ethanol to unprecedented levels, raw materials for ethanol production must become more diversified. Accordingly, sweet sorghum (Sorghum bicolor L. Moench) is a raw material that contains high concentrations of sugars that can be directly converted to ethanol by fermentation (Wu et al., 2010). Hybrids developed from these cultures in genetic improvement programs for ethanol production have been tested with good production prospects (Barcelos et al., 2013). Therefore, sorghum is presented as an interesting complementary option to sugarcane to compose the energy matrix, especially in the sugarcane off season (May et al., 2012). Considering that the increase in the sweet sorghum crop areas for ethanol production will likely lead to a significant increase in the quantities of sorghum bagasse that can be used for second generation ethanol production, the aim of this study was to determine the best acid hydrolysis condition of the hemicellulosic fraction of sweet sorghum bagasse and evaluate the hydrolysate fermentability by the pentose fermenting yeast $S$. stipitis.

\section{MATERIALS AND METHODS}

\section{Chemical characterization of sorghum bagasse}

Sweet sorghum bagasse (cultivar CVSW 80007) was kindly provided by Canavialis/Monsanto, São Paulo, Brazil. The biomass was ground in a Wiley mill to a particle size of 50 mesh, packed and stored at $-4{ }^{\circ} \mathrm{C}$. The biomass was dried at $105{ }^{\circ} \mathrm{C}$ to constant weight and characterized for the lignocellulosic composition, ash, moisture and extractives according the method described by the National Renewable Energy Laboratory - NREL (Sluiter et al., 2008a; Sluiter et al., 2008b).

\section{Evaluation of acid hydrolysis of sorghum bagasse}

A central composite design (CCD) and response surface methodology was proposed to study the acid hydrolysis of the hemicellulosic fraction of sorghum bagasse. The tests were conducted according a $2^{3}$ factorial design with four replications at the center point. The independent variables were the hydrolysis time in an autoclave $(40,50$, and $60 \mathrm{~min})$, sulfuric acid concentration $(0.75,1.25$ and $1.75 \% \mathrm{w} / \mathrm{v})$ and temperature $\left(111,115\right.$ and $\left.121^{\circ} \mathrm{C}\right)$. The real and coded values are shown in Table 1 . For each assay, $10 \mathrm{~g}$ of dry biomass were placed in $500 \mathrm{~mL}$ Erlenmeyer flasks, to which were added $200 \mathrm{~mL}$ of sulfuric acid. After 
Table 1. Matrix of the $2^{3}$ planning with the coded values, real values and the results of sugar concentration.

\begin{tabular}{|c|c|c|c|c|c|c|c|c|c|c|c|}
\hline \multirow[b]{2}{*}{ Assay } & \multicolumn{7}{|c|}{ Variable } & \multirow[b]{2}{*}{$\underset{(\mathrm{g} / \mathrm{L})}{\mathbf{A A}}$} & \multirow[b]{2}{*}{$\begin{array}{l}\text { Phenolics } \\
\text { (g/L) }\end{array}$} & \multirow[b]{2}{*}{$\begin{array}{c}\mathrm{HMF}(\mathrm{g} / \mathrm{L}) \\
(\mathrm{mg} / \mathrm{L})\end{array}$} & \multirow[b]{2}{*}{$\begin{array}{c}\text { Fur } \\
(\mathrm{mg} / \mathrm{L})\end{array}$} \\
\hline & $\begin{array}{l}\text { Temp } \\
\left({ }^{\circ} \mathrm{C}\right)\end{array}$ & $\begin{array}{c}\text { Time } \\
\text { (minutes) }\end{array}$ & $\begin{array}{c}\mathrm{H}_{2} \mathrm{SO}_{4} \\
(\%) \\
\end{array}$ & $\mathbf{p H}$ & $\begin{array}{l}\text { Ara } \\
(\mathrm{g} / \mathrm{L})\end{array}$ & $\begin{array}{c}\text { Xyl } \\
\text { (g/L) }\end{array}$ & $\begin{array}{c}\text { Glu } \\
\text { (g/L) }\end{array}$ & & & & \\
\hline 1 & $-1(111)$ & $-1(40)$ & $-1(0.75)$ & 1.15 & 2.61 & 2.2 & 1.08 & 0.78 & 0.58 & 40.36 & 403 \\
\hline 2 & $1(121)$ & $-1(40)$ & $-1(0.75)$ & 1.11 & 2.08 & 5.12 & 1.31 & 0.85 & 0.79 & 91.23 & 772 \\
\hline 3 & $-1(111)$ & $1(60)$ & $-1(0.75)$ & 1.13 & 1.92 & 1.75 & 0.69 & 0.93 & 0.42 & 52.87 & 481 \\
\hline 4 & 1 (121) & $1(60)$ & $-1(0.75)$ & 1.18 & 1.61 & 5.24 & 0.38 & 1.04 & 0.77 & 91.65 & 807 \\
\hline 5 & $-1(111)$ & $-1(40)$ & $1(1.75)$ & 0.95 & 1.22 & 9.55 & 1.81 & 1.29 & 0.65 & 62.85 & 571 \\
\hline 6 & $1(121)$ & $-1(40)$ & $1(1.75)$ & 1.02 & 0.95 & 14.22 & 2.42 & 1.34 & 0.90 & 124.54 & 978 \\
\hline 7 & $-1(111)$ & $1(60)$ & $1(1.75)$ & 1.08 & 0.5 & 8.27 & 1.78 & 1.32 & 0.59 & 48.46 & 638 \\
\hline 8 & $1(121)$ & $1(60)$ & $1(1.75)$ & 0.94 & 0.45 & 12.41 & 1.96 & 1.47 & 0.83 & 81.10 & 985 \\
\hline 9 & $0(115)$ & $0(50)$ & $0(1.25)$ & 1.02 & 1.45 & 7.24 & 1.35 & 1.11 & 0.72 & 69.90 & 712 \\
\hline 10 & $0(115)$ & $0(50)$ & $0(1.25)$ & 1.00 & 1.43 & 7.23 & 1.41 & 1.12 & 0.71 & 70.48 & 707 \\
\hline 11 & $0(115)$ & $0(50)$ & $0(1.25)$ & 1.03 & 1.46 & 7.27 & 1.38 & 1.15 & 0.72 & 68.81 & 713 \\
\hline 12 & $0(115)$ & $0(50)$ & $0(1.25)$ & 1.03 & 1.47 & 7.26 & 1.39 & 1.13 & 0.73 & 69.36 & 701 \\
\hline
\end{tabular}

Temp: temperature; Ara: arabinose; Xyl: xylose; Glu: glucose; AA: Acetic acid; HMF: hydroxymethylfurfural; Fur: Furfural.

hydrolysis, the hydrolysate was filtered and analyzed for $\mathrm{pH}$, concentration of xylose, glucose, arabinose, phenols, furfural, hydroxymethylfurfural (HMF) and acetic acid.

\section{Validation of acid hydrolysis experiments}

For validation of the results obtained during the $\mathrm{CCD}$, experiments were carried out at $121{ }^{\circ} \mathrm{C}$ and 40 min (best conditions obtained in the acid hydrolysis study) and varying the sulfuric acid concentration (1.45, $1.60,1.75,2.15$ and $2.30 \% \mathrm{w} / \mathrm{v})$. The hydrolysates obtained were evaluated for the concentration of xylose, glucose, arabinose, phenols, furfural, HMF and acetic acid.

\section{Bioethanol production from the hemicellulosic fraction of sweet sorghum bagasse}

Preparation of sorghum bagasse hemicellulosic hydrolysate

The sorghum bagasse hemicellulosic hydrolysate obtained under the optimized condition was used for ethanol production. Before fermentation, hydrolysate was three-fold concentrated under vacuum at $65^{\circ} \mathrm{C}$. Then it was detoxified by $\mathrm{pH}$ change and adsorption with activated charcoal (Marton et al., 2006). The detoxified concentrated hydrolysate was analyzed for sugars and toxic compounds.

\section{Microorganism and inoculum preparation}

The yeast utilized was Scheffersomyces stipitis ATCC 58376, maintained in Malt Extract Agar medium at $4{ }^{\circ} \mathrm{C}$. Inoculum preparation was carried out in $125 \mathrm{~mL}$ Erlenmeyer flasks containing $50 \mathrm{~mL}$ of YMP medium $(20 \mathrm{~g} / \mathrm{L}$ xylose, $3 \mathrm{~g} / \mathrm{L}$ malt extract, $3 \mathrm{~g} / \mathrm{L}$ yeast extract and $5 \mathrm{~g} / \mathrm{L}$ peptone) in a rotating incubator at $200 \mathrm{rpm}, 30{ }^{\circ} \mathrm{C}$ for 16 hours. Cells were recovered by centrifugation at $2000 \mathrm{x}$ g for $20 \mathrm{~min}$, rinsed twice with sterile distilled water, resuspended in sterile distilled water and used as inoculum at an initial cell concentration of $0.5 \mathrm{~g} / \mathrm{L}$.

\section{Fermentations conditions}

Fermentation was conducted in a bioreactor (Biotec $7.5 \mathrm{~V}$, Tecnal) with working volume of $4.5 \mathrm{~L}$. The detoxified concentrated hydrolysate was autoclaved at $121^{\circ} \mathrm{C}$ and supplemented with the same nutrients of the medium YMP (except xylose) and $\mathrm{pH}$ was adjusted to 5.5 with $\mathrm{NaOH}(0.5 \mathrm{~mol} / \mathrm{L})$. The $\mathrm{kLa}$ (oxygen transfer coefficient) was $4.9 \mathrm{~h}^{-1}$ (Silva et al., 2011), obtained with aeration of $0.25 \mathrm{vvm}$ and agitation of $200 \mathrm{rpm}$. After inoculation, the fermentation was conducted at $30{ }^{\circ} \mathrm{C}$ for 78 hours.

\section{Analytical methods}

The concentrations of glucose, xylose, arabinose, acetic acid and ethanol in the hydrolysates were determined by high-performance liquid chromatography (HPLC) using a liquid chromatograph (Shimadzu 20A), Rezex column ROA Oganic Acids $\mathrm{H}+(8 \%) 150 \times 7.8 \mathrm{~mm}$; mobile phase $\mathrm{H}_{2} \mathrm{SO}_{4} 0.005$ $\mathrm{mol} / \mathrm{L}$, flow rate $0.6 \mathrm{~mL} / \mathrm{min}$, oven temperature 65 ${ }^{\circ} \mathrm{C}$ and a refractive index detector. Before injection samples were purified in Sep-Pak C18 cartridges (Waters).

For the determination of furfural and HMF, the following conditions were used: Column Kinetex Phenomenex, C18, $5 \mu \mathrm{m}, 100 \mathrm{~A}, 150$ x $4.6 \mathrm{~mm}$; oven temperature $25^{\circ} \mathrm{C}$; ultraviolet detector (SPD-20A) at $208 \mathrm{~nm}$, mobile phase acetonitrile/water (1:8) with $1 \%$ acetic acid and flow rate $0.8 \mathrm{~mL} / \mathrm{min}$. Before injection samples were filtered in PTFE VertiPureTM (polytetrafluorethylene) syringe filters with pore size $0.45 \mu \mathrm{m}$ and diameter $13 \mathrm{~mm}$.

Total phenols were analyzed according to the Folin Ciocalteu method using a standard curve of vanillin (Singleton et al., 1999). The protein content was determined by the Kjeldahl method (AOAC, 1995). Cell concentration was determined by turbidimetry and calculated from a standard curve made by plotting dry weight of cells vs O.D. ${ }_{600 \mathrm{~nm}}$. 


\section{RESULTS AND DISCUSSION}

\section{Chemical characterization of lignocellulosic biomass}

Sweet sorghum bagasse presented 10.41\% ( \pm $0.49)$ humidity; $3.31 \%( \pm 0.34)$ ash; $8.74 \%( \pm 1.33)$ extractives and $4.76 \%( \pm 0.58)$ protein. Lignocellulosic composition was $36.08 \%$ ( \pm 1.13 ) cellulose, $31.18 \%$ ( \pm $0.79)$ hemicellulose and $24.77 \%( \pm 1.99)$ lignin, values similar to those described by Liu et al. (2012) for sweet sorghum bagasse, which were $39.07 \%$ cellulose and $34.57 \%$ hemicellulose, except lignin, $13.29 \%$. Kim and Day (2011) reported that the percentages of cellulose, hemicellulose and lignin in sweet sorghum bagasse were $45 \%, 27 \%$ and $21 \%$, respectively. The variations in the chemical composition of sorghum biomass may be the result of the cultivar type or geographic and environmental factors in which the plant was grown. For sugarcane bagasse, a biomass widely studied as raw material for bio-processes including bioethanol, reported percentages are between $38-42 \%$ of cellulose, $27-24 \%$ of hemicellulose, and $22-18 \%$ of lignin (Kim and Day., 2011; Guilherme et al., 2015).

According to the results shown above, sorghum bagasse emerges as an alternative biomass for bioprocesses which utilize not only the cellulosic fraction but also hemicellulose as a source of sugars.

\section{Statistical analysis of the acid hydrolysis}

Table 1 presents the planning matrix for the acid hydrolysis of sweet sorghum bagasse with the variables in their coded and real values (in parentheses) and the results for sugars and inhibitory compounds.

Test 6 (sulfuric acid concentration $1.75 \% \mathrm{w} / \mathrm{v}$, temperature $121{ }^{\circ} \mathrm{C}$ and hydrolysis time 40 minutes) resulted in the highest amounts of xylose $(14.22 \mathrm{~g} / \mathrm{L})$ and glucose $(2.42 \mathrm{~g} / \mathrm{L})$ (Table 1). After hydrolysis the glucose amounts were not superior to $2.42 \mathrm{~g} / \mathrm{L}$ for all conditions tested, which may be explained by the fact that under the mild conditions cellulose was not hydrolyzed, the glucose possibly arising from the side chains of hemicellulose. According to Liu et al. (2012) the glucose release during hydrolysis of cellulose begins to occur when the reaction temperature increases. In this regard, the glucose yield increases significantly at $150{ }^{\circ} \mathrm{C}$ after 120 minutes. Low concentrations of glucose in the hemicellulosic hydrolysates have been considered acceptable because glucose contributes to microbial growth in the early hours of fermentation and assists in increasing product yields such as ethanol and xylitol in pentose-fermenting microorganisms (Agbogbo et al., 2006; Canilha et al., 2008).

Table 2 shows the main effects and interactions of the factors obtained in the study of the acid hydrolysis of sorghum bagasse. The main linear effects for the concentrations of sugars and toxic compounds were statistically significant at the significance level of $5 \%$ $(\mathrm{p}<0.05)$.

The increase in the percentage of sulfuric acid from 0.75 to $1.75 \%$ promoted a positive effect on the glucose and xylose responses, resulting in 1.12 and 7.29-fold increases in the glucose and xylose concentrations in the hydrolysate, respectively. Regarding the temperature factor $(\mathrm{p}=0.000001)$, the variation from 111 to $121{ }^{\circ} \mathrm{C}$ increased the xylose concentration by 3.59 -fold. However, an increase of the hydrolysis time from 40 to 60 minutes contributed to reductions of 0.45 - and 0.59 -fold, respectively, for both of the sugars glucose and xylose $(\mathrm{p}<0.05)$.

The results of this study are in agreement with those of Poonsrisawat et al. (2013) who affirm that, for sorghum bagasse, temperature and sulfuric acid concentration were the variables which had a significant effect on glucose and xylose yields; however, the residence time had no significant effect.

The highest arabinose concentration (2.61 $\mathrm{g} / \mathrm{L}$ ) was obtained with the lower levels (-1) of all variables (sulfuric acid $0.75 \%, 111{ }^{\circ} \mathrm{C}$ and $40 \mathrm{~min}$ ), whereas under stronger conditions, arabinose suffered degradation (Table 1). Contrary to what was observed for glucose and xylose, the sulfuric acid factor $(p=$ 0.000002 ) had a negative effect on arabinose. The increase in the percentage of acid used $(0.75$ to $1.75 \%)$ reduced the concentration of this sugar by 1.27 -fold (Table 2). According to Liu et al. (2012), arabinose is released easily and is also susceptible to degradation into furfural at high temperatures.

With respect to inhibitor formation, the data presented in Table 1 show that the treatment 8, which consisted in the highest levels $(+1)$ of the variables (sulfuric acid $1.75 \%, 121{ }^{\circ} \mathrm{C}$ and 60 minutes) resulted in the highest release of acetic acid $(1.47 \mathrm{~g} / \mathrm{L})$. On the contrary, the lowest levels of the variables (-1) provided the lowest concentration of this inhibitor compound. Table 2 shows that acetic acid formation was favored by temperature $(p=0.001754)$, reaction time $(p=0.000795)$ and percentage of sulfuric acid $(p=0.000018)$, promoting increments of 0.09-, 0.12and 0.45 -fold, respectively, in the concentration of this acid in the hydrolyzate.

The strongest condition tested (sulfuric acid 1.75\%, $121^{\circ} \mathrm{C}$ and 60 minutes) also promoted an increase in the concentration of furfural (Table 1). This suggests that furfural formation was mainly related to the degradation of arabinose, as the concentrations of this sugar decreased upon increasing the acid concentration and temperature, as shown above.

From the results of Table 2 it is possible to verify statistically that the fator temperature exerted a more severe effect on the degradation of sugars into toxic compounds, resulting in increases of 44.99 and 362.25 fold for HMF and furfural, respectively. However, for the furfural response, besides the temperature 
Table 2. Main effects of the acid hydrolysis planning with variation in temperature, time, acid concentration and their interactions for the responses concentration of sugars and toxic compounds.

\begin{tabular}{|c|c|c|c|c|c|c|}
\hline Factor & Effect & Std.Err. & $t(3)$ & $\mathbf{p}$ & $-95 \%$ & $+95 \%$ \\
\hline \multicolumn{7}{|c|}{ Arabinose } \\
\hline Mean/Interc & 1.43 & 0.004 & 289.88 & 0.000000 & 1.40 & 1.44 \\
\hline (1L) Temperature $\left({ }^{\circ} \mathrm{C}\right)$ & -0.29 & 0.012 & -24.01 & 0.000158 & -0.33 & -0.25 \\
\hline (2L) Time (min) & -0.59 & 0.012 & -49.27 & 0.000019 & -0.63 & -0.55 \\
\hline$(3 \mathrm{~L})$ Acid $(\%)$ & -1.27 & 0.012 & 105.58 & 0.000002 & -1.31 & -1.23 \\
\hline $1 \mathrm{~L}$ by $2 \mathrm{~L}$ & 0.11 & 0.012 & 9.10 & 0.002796 & 0.07 & 0.14 \\
\hline $1 \mathrm{~L}$ by $3 \mathrm{~L}$ & 0.13 & 0.012 & 10.76 & 0.001714 & 0.09 & 0.16 \\
\hline $2 \mathrm{~L}$ by $3 \mathrm{~L}$ & -0.01 & 0.012 & -1.24 & 0.302445 & -0.05 & 0.02 \\
\hline \multicolumn{7}{|c|}{ Glucose $(\mathrm{g} / \mathrm{L})$} \\
\hline Mean/Interc & 1.41 & 0.0072 & 195.83 & 0.000000 & 1.39 & 1.43 \\
\hline (1L) Temperature $\left({ }^{\circ} \mathrm{C}\right)$ & 0.17 & 0.0176 & 10.04 & 0.002103 & 0.12 & 0.23 \\
\hline (2L) Time (min) & -0.45 & 0.0176 & -25.59 & 0.000131 & -0.50 & -0.39 \\
\hline$(3 \mathrm{~L})$ Acid $(\%)$ & 1.12 & 0.0176 & 63.78 & 0.000008 & 1.07 & 1.18 \\
\hline $1 \mathrm{~L}$ by $2 \mathrm{~L}$ & -0.24 & 0.0176 & -13.71 & 0.000838 & -0.29 & -0.18 \\
\hline $1 \mathrm{~L}$ by $3 \mathrm{~L}$ & 0.21 & 0.0176 & 12.30 & 0.001156 & 0.16 & 0.27 \\
\hline $2 \mathrm{~L}$ by $3 \mathrm{~L}$ & 0.20 & 0.0176 & 11.73 & 0.001329 & 0.15 & 0.26 \\
\hline \multicolumn{7}{|c|}{ Xylose } \\
\hline Mean/Interc & 7.22 & 0.0036 & 1989.26 & 0.000000 & 7.21 & 7.23 \\
\hline (1L) Temperature $\left({ }^{\circ} \mathrm{C}\right)$ & 3.59 & 0.0088 & 403.48 & 0.000001 & 3.56 & 3.61 \\
\hline (2L) Time (min) & -0.59 & 0.0088 & -66.87 & 0.000007 & -0.62 & -0.56 \\
\hline (3L) Acid $(\%)$ & 7.29 & 0.0088 & 819.88 & 0.000003 & 7.26 & 7.32 \\
\hline $1 \mathrm{~L}$ by $2 \mathrm{~L}$ & 0.22 & 0.0088 & 25.28 & 0.000136 & 0.19 & 0.25 \\
\hline $1 \mathrm{~L}$ by $3 \mathrm{~L}$ & 0.31 & 0.0088 & 35.40 & 0.000050 & 0.28 & 0.34 \\
\hline $2 \mathrm{~L}$ by $3 \mathrm{~L}$ & -0.45 & 0.0088 & -50.57 & 0.000017 & -0.47 & -0.42 \\
\hline \multicolumn{7}{|c|}{ Acetic acid } \\
\hline Mean/Interc & 1.12 & 0.0037 & 302.09 & 0.000000 & 1.11 & 1.13 \\
\hline (1L) Temperature $\left({ }^{\circ} \mathrm{C}\right)$ & 0.09 & 0.0091 & 10.68 & 0.001754 & 0.06 & 0.12 \\
\hline (2L) Time (min) & 0.12 & 0.0091 & 13.96 & 0.000795 & 0.09 & 0.15 \\
\hline (3L) Acid $(\%)$ & 0.45 & 0.0091 & 49.56 & 0.000018 & 0.42 & 0.48 \\
\hline $1 \mathrm{~L}$ by $2 \mathrm{~L}$ & 0.03 & 0.0091 & 3.56 & 0.037815 & 0.003 & 0.06 \\
\hline $1 \mathrm{~L}$ by $3 \mathrm{~L}$ & 0.007 & 0.0091 & 0.82 & 0.471524 & -0.02 & 0.03 \\
\hline $2 \mathrm{~L}$ by $3 \mathrm{~L}$ & -0.04 & 0.0091 & -4.65 & 0.018695 & -0.07 & -0.01 \\
\hline \multicolumn{7}{|c|}{ Phenolics } \\
\hline Mean/Interc & 0.69 & 0.0027 & 252.66 & 0.000000 & 0.68 & 0.70 \\
\hline (1L) Temperature $\left({ }^{\circ} \mathrm{C}\right)$ & 0.26 & 0.0067 & 38.77 & 0.000038 & 0.24 & 0.28 \\
\hline (2L) Time (min) & -0.07 & 0.0067 & -11.44 & 0.001431 & -0.09 & -0.05 \\
\hline (3L) Acid (\%) & 0.10 & 0.0067 & 15.14 & 0.000626 & 0.08 & 0.12 \\
\hline $1 \mathrm{~L}$ by $2 \mathrm{~L}$ & 0.03 & 0.0067 & 4.80 & 0.017203 & 0,01 & 0.054 \\
\hline $1 \mathrm{~L}$ by $3 \mathrm{~L}$ & -0.017 & 0.0067 & -2.58 & 0.081432 & -0.03 & 0.004 \\
\hline $2 \mathrm{~L}$ by $3 \mathrm{~L}$ & 0.012 & 0.0067 & 1.84 & 0.162008 & -0.009 & 0.03 \\
\hline \multicolumn{7}{|c|}{ HMF } \\
\hline Mean/Interc & 72.97 & 0.2091 & 348.91 & 0.000000 & 72.30 & 73.63 \\
\hline (1L) Temperature $\left({ }^{\circ} \mathrm{C}\right)$ & 44.99 & 0.5122 & 87.83 & 0.000003 & 43.36 & 46.62 \\
\hline (2L) Time ( $\mathrm{min})$ & -12.22 & 0.5122 & -23.86 & 0.000161 & -13.85 & -10.59 \\
\hline$(3 \mathrm{~L})$ Acid $(\%)$ & 11.21 & 0.5122 & 21.88 & 0.000209 & 9.57 & 12.84 \\
\hline $1 \mathrm{~L}$ by $2 \mathrm{~L}$ & -9.28 & 0.5122 & -18.12 & 0.000366 & -10.91 & -7.65 \\
\hline $1 \mathrm{~L}$ by $3 \mathrm{~L}$ & 0.17 & 0.5122 & 0.33 & 0.761841 & -1.46 & 1.80 \\
\hline $2 \mathrm{~L}$ by $3 \mathrm{~L}$ & -18.69 & 0.5122 & -36.48 & 0.000045 & -20.32 & -17.05 \\
\hline \multicolumn{7}{|c|}{ Furfural } \\
\hline Mean/Interc & 705.66 & 1.5877 & 444.45 & 0.000000 & 700.61 & 710.71 \\
\hline (1L) Temperature $\left({ }^{\circ} \mathrm{C}\right)$ & 362.25 & 3.8890 & 93.14 & 0.000003 & 349.87 & 374.62 \\
\hline (2L) Time (min) & 46.75 & 3.8890 & 12.02 & 0.001239 & 34.37 & 59.12 \\
\hline (3L) Acid $(\%)$ & 177.25 & 3.8890 & 45.57 & 0.000023 & 164.87 & 189.62 \\
\hline $1 \mathrm{~L}$ by $2 \mathrm{~L}$ & -25.75 & 3.8890 & -6.62 & 0.007016 & -38.12 & -13.37 \\
\hline $1 \mathrm{~L}$ by $3 \mathrm{~L}$ & 14.75 & 3.8890 & 3.79 & 0.032165 & 2.37 & 27.12 \\
\hline $2 \mathrm{~L}$ by $3 \mathrm{~L}$ & -9.7500 & 3.8890 & -2.50 & 0.087166 & -22.12 & 2.62 \\
\hline
\end{tabular}

$(\mathrm{p}=0.000003)$, the fator time $(\mathrm{p}=0.001239)$ and percentage of sulfuric acid $(\mathrm{p}=0.000023)$ also promoted increments of furfural concentration in the hydrolysate by 46.75 and 177.25 -fold, respectively.
Jeevan et al. (2011) found that furfural and HMF levels increased when increasing the reaction time and the sulfuric acid concentration in optimization studies of the acid hydrolysis of corn cobs. 
The interaction of the factors temperature $\mathrm{x}$ reaction time, as well as the interaction time $\mathrm{x}$ acid concentration had a negative effect $(p<0.05)$ on the formation of furfural and HMF, since they reduced the formation of these compounds in the hydrolysate. For HMF it was verified that the factors time and acid concentration together $(\mathrm{p}=0.000045)$ reduced the formation of this compound by 18.69 -fold, followed by the interaction of the factors temperature and reaction time $(\mathrm{p}=0.000366)$, with a reduction in the order of 9.28-fold. For furfural, the interaction temperature $\mathrm{x}$ reaction time $(\mathrm{p}=0.007016)$ led to a decrease of this inhibitor formation by 25.75 -fold, while the factor reaction time $x$ acid concentration $(p=0.087166)$ was not significant. The interaction temperature $\mathrm{x}$ acid concentration $(p=0.032165)$ favored the formation of fufural, increasing the concentration of this compound by 14.75-fold. Qi et al. (2008) found that the xylose degradation rate is faster than for glucose and the kinetic constant for degradation of xylose is mainly dependent on the temperature and hydrogen ion concentration.

With respect to the phenolic compounds, when the variables temperature, acid concentration and the interaction temperature $\mathrm{x}$ acid concentration were increased from the level $(-1)$ to $(+1)$ there was an increase in the concentration of phenolics. On the other hand, when time was increased from 40 to 60 minutes there was a decreased response for phenolics concentration. However, the interactions temperature $\mathrm{x}$ time and sulfuric acid concentration $\mathrm{x}$ time are below the significance limit.

According to the literature, the inhibitor concentrations vary for each type of biomass and hydrolysis condition employed. Zhang et al. (2015) obtained $0.99 \mathrm{~g} / \mathrm{L}$ of acetic acid, $12.22 \mathrm{~g} / \mathrm{L}$ of furfural, $0.73 \mathrm{~g} / \mathrm{L}$ of HMF and $1.60 \mathrm{~g} / \mathrm{L}$ of phenolics during hydrolysis of sorghum bagasse at $170{ }^{\circ} \mathrm{C}$, acid concentration of $1.0 \%(\mathrm{w} / \mathrm{w})$ and $10 \mathrm{~min}$ of reaction, a condition that resulted in the highest glucose concentration $(70 \%)$. Concentrations values ranging from $0.25 \mathrm{~g} / \mathrm{L}$ to $0.54 \mathrm{~g} / \mathrm{L}$ furfural, $0.06 \mathrm{~g} / \mathrm{L}$ to 1.56 $\mathrm{g} / \mathrm{L} \mathrm{HMF}, 1.87$ to $2.80 \mathrm{~g} / \mathrm{L}$ of acetic acid and 0.22 to $2.12 \mathrm{~g} / \mathrm{L}$ phenolic were observed for corncob (Zhang et al., 2015; Ping et al., 2013), sorghum straw (Sene et al., 2011) and sugarcane bagasse (Martin et al., 2007). Thus, the wide range of the reported inhibitory concentrations depends on the type of biomass, hydrolysis conditions, severity of the treatment employed and the experimental conditions used in each experiment.

\section{Analysis of variance}

The analysis of variance (ANOVA) demonstrated that the proposed model is valid and that the equation parameters fit the experimental data for arabinose, glucose and xylose, i.e., that the first order model (linear) was significant. Moreover, the coefficient of determination $\left(\mathrm{R}^{2}\right)$ was high, which indicates that the linear mathematical model for the production of sugars was valid for all the three cases.

The equations to predict the response variables are presented according to the coded values of the independent variables, indicating the statistically significant values at a confidence level of $95 \%$ for arabinose (Equation 1), glucose (Equation 2) and xylose (Equation 3). The statistically non-significant parameters (interaction time $\mathrm{x}$ acid concentration for arabinose) were eliminated from the model.

For the phenolic and HMF content, despite the lack of significant adjustment, the model can still be considered valid for predictive purposes, because the results showed high determination coefficient (R2> 0.96 ) at $95 \%$ confidence. For acetic acid (Equation 4) and furfural (Equation 5) the model exhibited no significant lack of fit, indicating that the predictive equation can be used for any combination of the variable values.

$$
\begin{aligned}
\operatorname{Arabinose}(\mathrm{g} / \mathrm{L}) & =1.43-0.29 \mathrm{X}_{1}-0.59 \mathrm{X}_{2}-1.27 \mathrm{X}_{3}+ \\
& +0.11 \mathrm{X}_{1} \mathrm{X}_{2}+0.13 \mathrm{X}_{1} \mathrm{X}_{3}
\end{aligned}
$$

$\begin{aligned} \operatorname{Glucose}(\mathrm{g} / \mathrm{L}) & =1.41+0.17 \mathrm{X}_{1}-0.45 \mathrm{X}_{2}+1.12 \mathrm{X}_{3}- \\ & -0.24 \mathrm{X}_{1} \mathrm{X}_{2}+0.21 \mathrm{X}_{1} \mathrm{X}_{3}+0.20 \mathrm{X}_{2} \mathrm{X}_{3}\end{aligned}$

Xylose $(\mathrm{g} / \mathrm{L})=7.22+3.59 \mathrm{X}_{1}-0.59 \mathrm{X}_{2}+7.29 \mathrm{X}_{3}+$ $+0.22 \mathrm{X}_{1} \mathrm{X}_{2}+0.31 \mathrm{X}_{1} \mathrm{X}_{3}-0.45 \mathrm{X}_{2} \mathrm{X}_{3}$

$\operatorname{Acetic} \operatorname{acid}(\mathrm{g} / \mathrm{L})=1.12+0.097 \mathrm{X}_{1}+0.127 \mathrm{X}_{2}+0.452 \mathrm{X}_{3}+$ $+0.03 \mathrm{X}_{1} \mathrm{X}_{2}-0.04 \mathrm{X}_{1} \mathrm{X}_{3}$

$\operatorname{Furfural}(\mathrm{g} / \mathrm{L})=705.66+362.25 \mathrm{X}_{1}+46.75 \mathrm{X}_{2}+177.25 \mathrm{X}_{3}-$ $-25.75 \mathrm{X}_{1} \mathrm{X}_{2}+14.75 \mathrm{X}_{1} \mathrm{X}_{3}$

where $\mathrm{X}_{1}$ is the encoded value for temperature, $\mathrm{X}_{2}$ is the encoded value for time and $X_{3}$ the encoded value for acid concentration.

\section{Surface response for the production of sugars and toxic compounds}

The response surfaces were generated for arabinose, glucose and xylose (Figure 1) and inhibitors (Figure 2) on the basis of the significant factors of the independent variables.

The response surface of arabinose shows that the lowest temperature $\left(111{ }^{\circ} \mathrm{C}\right)$, the shortest time (40 minutes) and lowest acid concentration $(0.75 \%)$ resulted in the highest amount of arabinose in the sorghum bagasse hemicellulosic hydrolysate. 

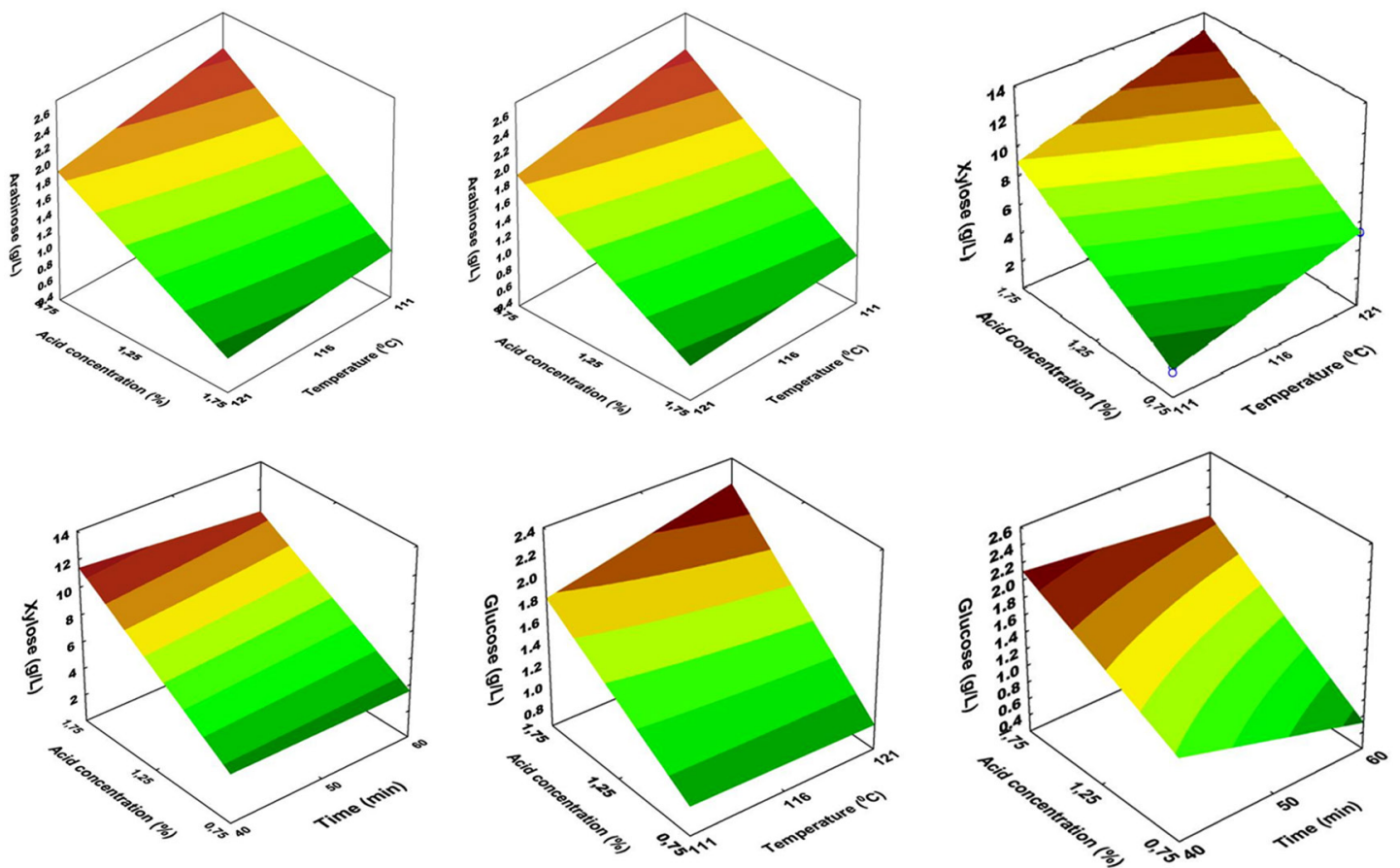

Figure 1. Response surfaces for the concentrations of arabinose, xylose and glucose obtained from the acid hydrolysis of sorghum bagasse.
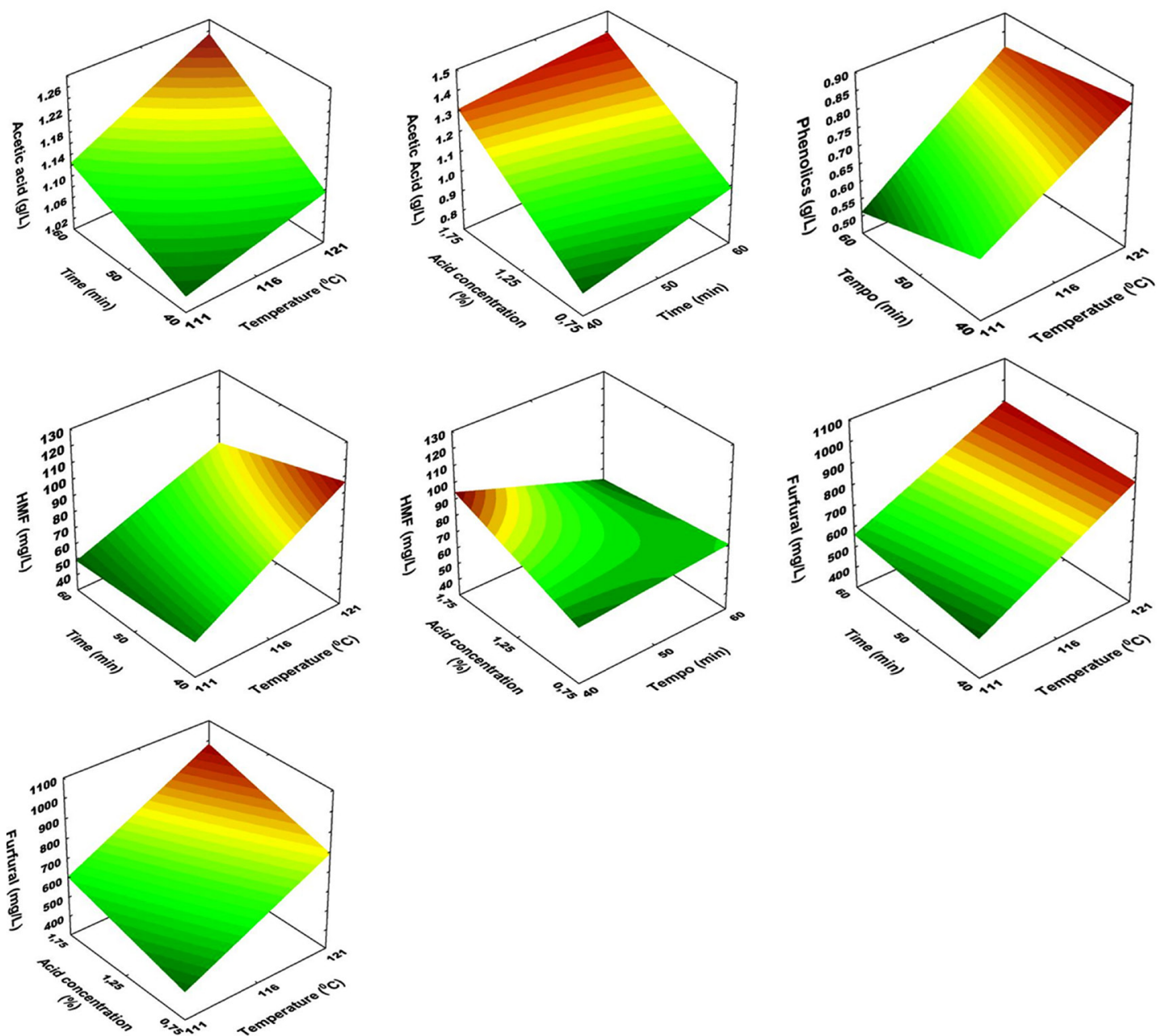

Figure 2. Response surfaces for the concentrations of acetic acid, phenolics, furfural and HMF obtained from acid hydrolysis of sorghum bagasse. 
For glucose, the high level $(+1)$ of temperature $\left(121{ }^{\circ} \mathrm{C}\right)$ and acid concentration $(1.75 \%)$ resulted in the highest amount of glucose. In contrast, the independent variable time at the low level (-1) resulted in high glucose concentration in the hydrolysate.

The response surface plot for xylose, similar to that observed for glucose, shows that the acid concentration and temperature were the variables that most favored the hydrolysis of hemicellulose to xylose. The best xylose yields were obtained using an acid concentration of $1.75 \%$ and hydrolysis temperature of $121{ }^{\circ} \mathrm{C}$.

Camargo et al. (2015) described similar levels of xylose in the forage sorghum bagasse hemicellulosic hydrolysate (16.76 - $17.42 \mathrm{~g} / \mathrm{L})$ when hydrolysis was carried out with $2 \%$ sulfuric acid at $121{ }^{\circ} \mathrm{C}$ for 70 minutes. With sorghum straw, Sene et al. (2011) obtained higher concentrations of xylose $(17.69 \mathrm{~g} / \mathrm{L})$ and less glucose $(2.1 \mathrm{~g} / \mathrm{L})$ and arabinose $(1.81 \mathrm{~g} / \mathrm{L})$ than those found in the present work.

With regard to inhibitors, the response surface plot for acetic acid shows that the release of acetic acid was favored when the high levels of variables were employed. For the phenolic compounds, it is possible to observe that higher concentrations were obtained with the lowest hydrolysis time (40 minutes) and highest temperature $\left(121^{\circ} \mathrm{C}\right)$.

For HMF the higher the temperature and concentration of the catalyst, the higher the amount of HMF. Similarly, the formation of furfural occured with the increase of temperature and acid concentration, indicating that to obtain lower concentrations of this toxic compound milder hydrolysis conditions should be used. The time, in turn, did not presented a significant effect on these results.

\section{Experimental validation}

For the model validation, a new hydrolysis assay was run at $121{ }^{\circ} \mathrm{C}$ for 40 minutes, which were considered to be the best temperature and time during the CCD study for obtaining a hydrolysate rich in xylose. However, in these assays, the percent of sulfuric acid was varied $(1.45,1.60,1.75,2.15$ and $2.30 \%)$. The results are shown in Figure 3.

The highest concentration of xylose $(13.31 \mathrm{~g} / \mathrm{L})$ was obtained when the acid percentage was $1.75 \%$, confirming that this was the best condition for obtaining this sugar with low occurrence of furfural degradation. Glucose concentration also increased when the acid percentage increased and the highest glucose concentration value $(3.36 \mathrm{~g} / \mathrm{L})$ was obtained with $2.30 \%$ of sulfuric acid.

With respect to the inhibitors, an increase was observed in the concentrations of acetic acid, phenols, furfural and HMF when increasing the temperature to $121{ }^{\circ} \mathrm{C}$, even at lower sulfuric acid concentrations. The highest acetic acid concentration $(29.1 \mathrm{~g} / \mathrm{L})$, total

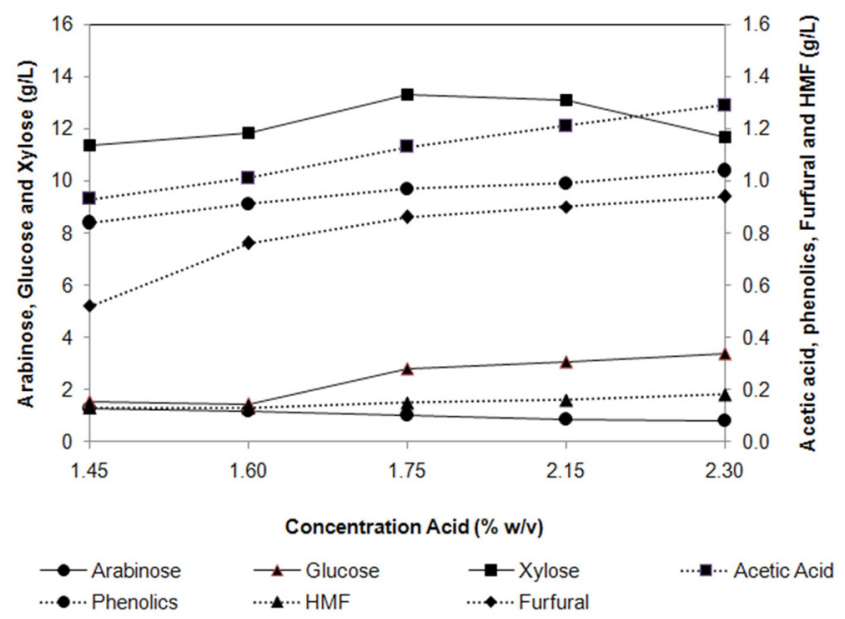

Figure 3. Variation of the concentration of sugars (arabinose, glucose, xylose) and toxic compounds (acetic acid, phenolics, furfural and HMF) obtained with the variation of sulfuric acid concentration during the hydrolysis of the hermicellulosic fraction of sweet sorghum bagasse.

phenolics (1.04 g/L), HMF (158.21 mg/L) and furfural $(946.82 \mathrm{mg} / \mathrm{L})$ were obtained with $2.30 \% \mathrm{H}_{2} \mathrm{SO}_{4}$.

These results, therefore, confirm the validity of the model adopted, in which it is assumed that the variables time at the low level (-1) (40 minutes) and the variables temperature and acid concentration at the high level $(+1)\left(121{ }^{\circ} \mathrm{C} ; 1.75 \%\right)$, as observed previously (Table 1), compose the best condition for obtaining a hemicellulosic hydrolysate rich in sugars (mainly xylose) and low concentrations of inhibitory compounds.

Heredia-Olea et al. (2012), studying the total amounts of C6 sugars (cellobiose and glucose), C5 sugars (xylose and arabinose) and inhibitory compounds (acetic acid, HMF and furfural) generated by different acid treatments (sulfuric and hydrochloric), also found through surface response methodologies a high coefficient of determination $\left(\mathrm{R}^{2}\right)$ for the responses for treatment with sulfuric acid. In addition, they also observed that their equations predicted the real experimental values, although the quadratic effect was better adjusted to the model. The response surface behavior for sulfuric acid showed that higher amounts of sugars were released when higher acid concentrations and hydrolysis times were used

In the present work, the values for xylose were different from those predicted by the model $(17.59 \mathrm{~g} / \mathrm{L})$ probably because the increase in acid concentration propitiated sugar degradation and inhibitor formation.

This situation in which the amount of xylose released is different from the value predicted by the model, even though a high mathematical correlation was obtained $(90 \%)$, was also observed by HerediaOlea et al. (2012) during acidic hydrolysis of sweet sorghum bagasse with sulfuric acid. According to the 
authors, the prediction of the various acid treatments was underestimated compared to the expected and real values after the application of optimal treatments due to the high presence of inhibitory compounds, which indicated severe hydrolysis conditions for the raw material

\section{Characterization of the original, concentrated and detoxified hydrolysates}

The sorghum bagasse hemicellulosic hydrolysate obtained with $1.75 \%$ sulfuric acid at $121{ }^{\circ} \mathrm{C}$ for 40 minutes presented in its composition: glucose 2.42 $\mathrm{g} / \mathrm{L}$, xylose $15.22 \mathrm{~g} / \mathrm{L}$, arabinose $0.95 \mathrm{~g} / \mathrm{L}$, phenols 0.9 $\mathrm{g} / \mathrm{L}$, acetic acid $1.34 \mathrm{~g} / \mathrm{L}$, furfural $950.01 \mathrm{mg} / \mathrm{L}$ and HMF $124.54 \mathrm{mg} / \mathrm{L}$. After the concentration process, arabinose, glucose and xylose increased by $2.6 ; 3.6$ and 2.5 fold, respectively, compared to the hydrolysate in natura, while the ratio of increase of the inhibitor compounds was 1.8 to 2.15 fold.

After hydrolysate detoxification, the following composition was found: glucose $2.89 \mathrm{~g} / \mathrm{L}$, xylose 42.05 $\mathrm{g} / \mathrm{L}$, arabinose $1.66 \mathrm{~g} / \mathrm{L}$, phenols $0.65 \mathrm{~g} / \mathrm{L}$, acetic acid $0.78 \mathrm{~g} / \mathrm{L}$, furfural $650.12 \mathrm{mg} / \mathrm{L}$ and HMF $88.07 \mathrm{mg} / \mathrm{L}$. Therefore, the toxic compounds were partially removed in a ratio of approximately $70 \%$ compared to the nondetoxified hydrolysate. Sugar losses corresponded to $22 \%, 32 \%$ and $53 \%$ for xylose, arabinose and glucose, respectively. However, in sugarcane bagasse hemicellulosic hydrolysate detoxified with the same methodology used in this study, minor losses were found, representing $17 ; 15$ and $20 \%$ for xylose, arabinose and glucose, respectively (Antunes et al., 2014).

\section{Fermentability of sorghum bagasse hemicellulosic hydrolysate}

Figure 4 exhibits the cell growth, glucose and xylose consumption and ethanol production by S. stipitis yeast in sweet sorghum bagasse hemicellulosic hydrolysate during 76 hours. The adaptation phase of the yeast lasted 8 hours, followed by intense cell division until 48 hours, when cell concentration reached $12 \mathrm{~g} / \mathrm{L}$. From that moment, there was no increase in microbial biomass. When Chaud et al. (2012) used this same yeast grown in oat hull hemicellulosic hydrolysate (40 $\mathrm{g} / \mathrm{L}$ xylose) a final biomass concentration close to 6 $\mathrm{g} / \mathrm{L}$ was observed in 72 hours fermentation.

According to Aloisio et al. (2014) S. stipitis was capable of converting glucose, xylose and mixtures of glucose/xylose to ethanol. Although this microorganism had no lag phase in a medium with glucose, in the presence of xylose a lag phase was verified that lasted 4-5 hours. In this work, xylose was consumed throughout the fermentation process, even concomitantly with glucose. It was observed that $99 \%$ of xylose had been used by the yeast at the end of 76 hours.

Arabinose assimilation (data not shown) was not observed during the fermentation process. This behavior is consistent with the results reported in other works during fermentation with $S$. stipitis (Chaud et al., 2012; Silva et al., 2014).

Figure 4a shows that ethanol production increased from the $10^{\text {th }}$ hour of fermentation, reaching a maximum concentration of ethanol $(22 \mathrm{~g} / \mathrm{L})$ at 55 hours. Slightly higher values (ethanol $26 \mathrm{~g} / \mathrm{L}$ and cell concentration $15 \mathrm{~g} / \mathrm{L})$ were reported with $S$. stipitis yeast in synthetic medium $(90 \mathrm{~g} / \mathrm{L}$ xylose and $15 \mathrm{~g} / \mathrm{L}$ glucose) in a bioreactor with a $\mathrm{k}_{\mathrm{L}} 4.9 \mathrm{~h}^{-1}$ after 96 hours of fermentation (Silva et al., 2012).

In this work, due to the sugars exhaustion, ethanol was used as carbon source and decreased to $18 \mathrm{~g} / \mathrm{L}$ at the end of 76 hours. Ethanol consumption has also been observed by other authors with this same yeast (Stoutenburg et al., 2008; Fu et al., 2009; Ferreira et al., 2011). In a study to assess the volumetric oxygen transfer coefficient for ethanol production from xylose by $S$. stipitis, the maximum ethanol production $(13.5$
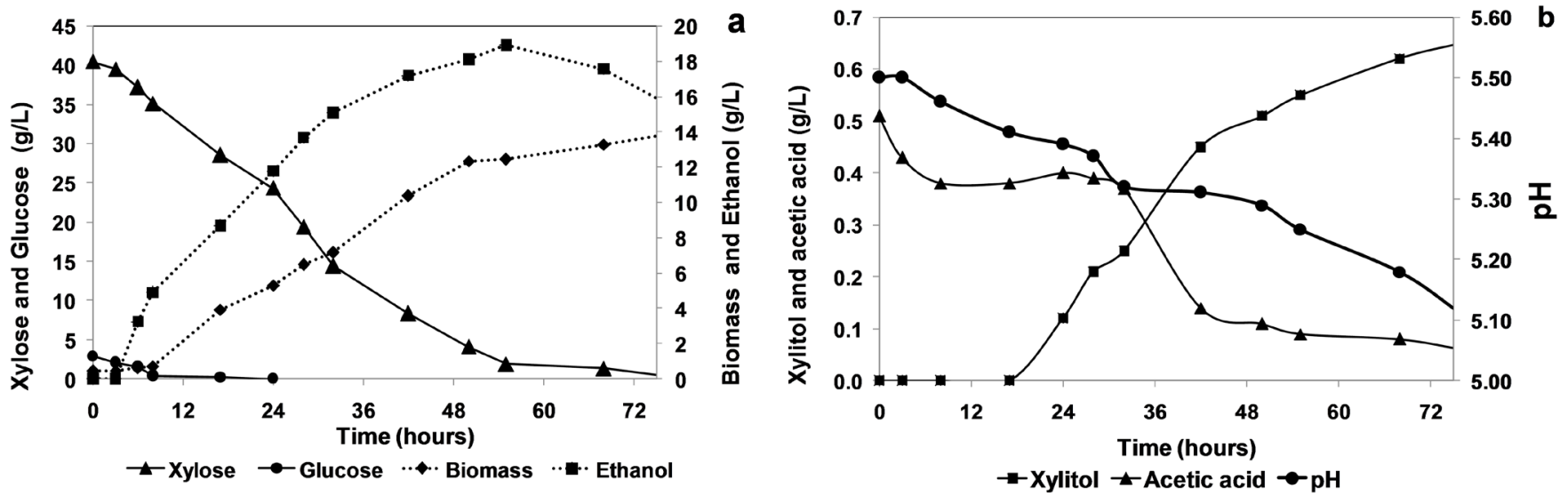

Figure 4. Cell growth, xylose and glucose consumption and ethanol production (a); acetic acid and pH variation and xylitol production (b) during fermentation of sweet sorghum bagasse hemicellulosic hydrolysate with Scheffersomyces stipitis ATCC 58376. 
$\mathrm{g} / \mathrm{L}$ ) was verified with a $\mathrm{kLa}$ of $18.7 \mathrm{~h}^{-1}$ at $36 \mathrm{~h}$ of fermentation and then, part of the ethanol produced was assimilated when xylose was still available (40 $\mathrm{g} / \mathrm{L}$ ). In this case, ethanol assimilation by the yeast suggests that oxygen was supplied in excess in the medium (Silva et al., 2012). According to Liu et al. (2012) ethanol production by S. stipitis is strongly affected by the intracellular redox state. Therefore, ethanol production occurs under relatively low oxygen condition, while ethanol is reassimilated when the oxygen content is excessive.

The maximum ethanol yield $\mathrm{Y}_{\mathrm{P} / \mathrm{S}}(12.40 \mathrm{~g} / \mathrm{g})$ and volumetric productivity $\mathrm{Qp}(0.34 \mathrm{~g} / \mathrm{L} . \mathrm{h})$ obtained in this study after 55 hours of fermentation are comparable or even higher than those found in the literature for ethanol production in hemicellulosic hydrolysates of different materials. For example, when the same yeast strain used in this study was grown in sunflower meal hemicellulosic hydrolysate, the maximum $\mathrm{Y}_{\mathrm{P} / \mathrm{S}}$ obtained was $0.23 \mathrm{~g} / \mathrm{g}$ and $\mathrm{Q}_{\mathrm{p}} 0.12 \mathrm{~g} / \mathrm{L} . \mathrm{h}$ (Camargo and Sene, 2014). Ethanol production by S. stipitis DSM 3651 in sugarcane bagasse hemicellulosic hydrolysate resulted in $Y_{P / S} 0.30 \mathrm{~g} / \mathrm{g}$ and $Q_{\mathrm{p}} 0.16 \mathrm{~g} / \mathrm{L}$.h (Canilha et al., 2010). With S. stipitis NRRL 7154 grown in wheat straw hemicellulosic hydrolysate $Y_{P / S} 0.41 \mathrm{~g} / \mathrm{g}$ and $Q_{p} 0.54$ $\mathrm{g} / \mathrm{L}$.h were obtained (Nigam, 2001). Dussán et al. (2016) evaluated the influence of aeration, agitation rate and initial $\mathrm{pH}$ on ethanol production by $S$. stipitis NRRL Y-7124 in sugarcane bagasse hemicellulosic hydrolysate and obtained better results: $Y_{P / S} 0.42 \mathrm{~g} / \mathrm{g}, Q_{\mathrm{P}} 0.25 \mathrm{~g} / \mathrm{L} . \mathrm{h}$ and $85 \%$ efficiency, using $100 \mathrm{rpm}$, initial $\mathrm{pH} 6.50$ in limiting conditions of oxygen $\left(0.7 \mathrm{vvm}\right.$ and. $\left.\mathrm{kLa} 0.1 \mathrm{~h}^{-1}\right)$.

Values similar to those reported in this work were obtained in synthetic medium comprising $35 \mathrm{~g} / \mathrm{L}$ glucose and $20 \mathrm{~g} / \mathrm{L}$ xylose during the study of the effect of different aeration rates on ethanol production by $S$. stipitis DSM 3651 (Bellido et al., 2013). The authors obtained $22.33 \mathrm{~g} / \mathrm{L}$ ethanol, $\mathrm{Y}_{\mathrm{P} / \mathrm{S}} 0.40 \mathrm{~g} / \mathrm{g}$ and $\mathrm{Q}_{\mathrm{P}} 0.30$ $\mathrm{g} / \mathrm{L}$.h with $\mathrm{kLa} 3.3 \mathrm{~h}^{-1}$ in 72 hours of fermentation. In a synthetic medium with $60 \mathrm{~g} / \mathrm{L}$ of sugars $(30 \mathrm{~g} / \mathrm{L}$ xylose and $30 \mathrm{~g} / \mathrm{L}$ glucose) using $S$. stipitis CCUG18492, Rouhollah et al. (2007) obtained a maximum of $30 \mathrm{~g} / \mathrm{L}$ of ethanol, with ethanol and cells yields of $0.40 \mathrm{~g} / \mathrm{g}$ and $0.08 \mathrm{~g} / \mathrm{g}$, respectively, but a much higher productivity value $(0.95 \mathrm{~g} / \mathrm{L} . \mathrm{h})$.

In fermentations of the sorghum bagasse hydrolysates pretreated with $1.28 \% \mathrm{HCl}$, bagasse:liquid ratio $6 \% \mathrm{w} / \mathrm{v}, 121{ }^{\circ} \mathrm{C}$ and fibrolytic enzyme complex (Novozymes) with the strains Saccharomyces cerevisiae ATCC $20252^{\mathrm{TM}}$, Pichia stipitis ATCC $66278^{\mathrm{TM}}$, and Issatchenkia orientalis ATCC $20381^{\mathrm{TM}}$ all fermentations reached the maximum ethanol concentration after 24 hours. However, both yeasts $S$. cerevisiae and $I$. orientalis produced significant amounts of ethanol, 183.9 and $209.2 \mathrm{mg} / \mathrm{g}$ ethanol, respectively, while $P$. stipitis was unable to consume significant amounts of xylose and glucose during 72 $\mathrm{h}$ fermentation, producing minimal amounts of this alcohol $(2.8 \mathrm{mg} / \mathrm{g})$. According to the authors, P. stipitis was inhibited by the presence of toxic compounds such as acetic acid, HMF that were in sufficient concentrations $(27.8,4.8,4.1 \mathrm{mg} / \mathrm{g}$ respectively), but did not significantly affect the other two strains of yeast. In addition, the fermentations were performed under anaerobic conditions and $P$. stipitis needs oxygen to generate ethanol (Heredia-Olea et al., 2013).

Figure $4 \mathrm{~b}$ shows the variation of $\mathrm{pH}$ and the production of acetic acid and xylitol during the fermentation of sorghum bagasse hemicellulosic hydrolysate by $S$. stipitis. A decrease of acetic acid concentration was noted over time, which was more pronounced at the $30^{\text {th }}$ hour, corresponding to an assimilation as carbon source of $88 \%$.

Acetic acid consumption has been observed in other yeast species. During xylitol production by $C$. guilliermondii FTI 20037 in sorghum straw hemicellulosic hydrolysate containing $3.13 \mathrm{~g} / \mathrm{L}$ of acetic acid a consumption was observed of about $28 \%$ after 72 hours (Sene et al., 2011). An assimilation of acetic acid higher than $70 \%$ was observed in C. guilliermondii FTI 20037 and S. stipitis NRRL Y-7124 during the fermentation of sugarcane bagasse hemicellulosic hydrolysate containing $2.5 \mathrm{~g} / \mathrm{L}$ of acetic acid. According to the authors, it is possible that the acetic acid was used for cell growth while xylose could have been used for the formation of ethanol and xylitol by $C$. guilliermondii and $S$. stipitis, respectively (Silva et al., 2014). Despite the consumption of acetic acid, a slight $\mathrm{pH}$ reduction was observed during the process, probably due the excretion of other acidic metabolites not evaluated in this work.

At the end of the fermentation the xylitol concentration reached $0.6 \mathrm{~g} / \mathrm{L}$. A similar amount of xylitol $(0.81 \mathrm{~g} / \mathrm{L})$ and $17.7 \mathrm{~g} / \mathrm{L}$ ethanol were observed in the fermentation of $S$. stipitis Y-7124 with an initial xylose concentration of $50 \mathrm{~g} / \mathrm{L}$ (Lee et al., 2000). Higher xylitol concentrations $(1.48 \mathrm{~g} / \mathrm{L})$ were obtained during the fermentation of hemicellulose hydrolysate from sunflower meal $(20.66 \mathrm{~g} / \mathrm{L}$ glucose and 24.09 $\mathrm{g} / \mathrm{L}$ xylose) by the same yeast strain used in this study (Camargo and Sene, 2014). Xylitol formation and its accumulation in the medium are attributed to a cellular response to environmental adversities such as redox imbalance caused under oxygen limitation, high substrate concentration, or the presence of inhibitors that may be generated during pre-treatment, especially under high severity conditions of hydrolysis (Betancur and Pereira, 2010).

\section{CONCLUSION}

Central composite design (CCD) and response surfaces allowed the evaluation of the acid hydrolysis of the hemicellulosic fraction of sweet sorghum 
bagasse. The concentration of sulfuric acid was the factor that had the greatest influence on the hydrolysis of hemicellulose. Acid hydrolysis with $1.75 \%$ of sulfuric acid at $121{ }^{\circ} \mathrm{C}$ for 40 minutes was the condition that provided the highest sugar content and the lowest toxic compounds levels in the hemicellulosic hydrolysate. Furthermore, the model responded satisfactorily to the study and the concentration of sugar corresponded to the predicted values for the validation. S. stipitis was able to grow in the sorghum bagasse hemicellulosic hydrolysate, consuming efficiently sugars (xylose 99\%) and producing $22 \mathrm{~g} / \mathrm{L}$ ethanol, with ethanol yield similar to those found for this yeast in hydrolysates from other types of biomass. Therefore, sweet sorghum bagasse was demonstrated to be a promising raw material, mainly for fermentation processes that employ pentoses as carbon sources.

\section{NOMENCLATURE}

$\begin{array}{ll}\text { ANOVA } & \text { Analysis of variance } \\ \text { CCD } & \text { Central composite design } \\ \text { HMF } & \text { Hydroxymethylfurfural } \\ \text { HPLC } & \begin{array}{l}\text { High-performance liquid } \\ \text { chromatography }\end{array} \\ \text { kLa } & \text { Oxygen transfer coefficient } \\ \text { NREL } & \begin{array}{l}\text { National Renewable Energy } \\ \text { Laboratory }\end{array} \\ \text { O.D. } & \text { Optical density } \\ \text { pH } & \text { Potential of hydrogen ion } \\ \text { PTFE } & \text { Polytetrafluoroethylene } \\ \text { Q }_{\mathrm{p}} & \text { Volumetric productivity } \\ \text { YMP } & \text { Yeast malt peptone } \\ \mathrm{Y}_{\text {P/S }} & \text { Ethanol yield }\end{array}$

\section{ACKNOWLEDGEMENT}

The authors acknowledge the Brazilian National Research Council (CNPq) for the doctoral scholarship granted to Danielle Camargo.

\section{REFERENCES}

Agbogbo, F.K. and Coward-Kelly, G., Cellulosic ethanol production using the naturally occurring xylose-fermenting yeast Pichia stipiti. Biotechnol Lett, 30, 1515-1524 (2008). https://doi.org/10.1007/ s10529-008-9728-z

Agbogbo, F.K. Coward-Kelly, G, Torry-Smith, M and Wenger, K.S., Fermentation of glucose/xylose mixtures using Pichia stipitis. Process Biochem, 41, 2333-2336 (2006). https://doi.org/10.1016/j. procbio. 2006.05 .004

Aloisio, L., Santis, A., Spera, D.M., Pignatelli, V. and Albergo, R., Innovative of second generation ethanol production from biomass crops by Pichia stipitis. Chem Eng Trans, 38, 115-120 (2014).
Antunes, F.A.F., Chandel, A.K., Milessi, T.S.S., Santos, J.C., Rosa, C.A. And Silva, S.S., Bioethanol production from sugarcane bagasse by a novel brazilian pentose fermenting yeast Scheffersomyces shehatae UFMG-HM 52.2: evaluation of fermentation medium. Intl J Cheml Eng, 2014, 1-8 (2014). https://doi.org/10.1155/2014/180681

Barakat, A., Monlau, F., Steyer, J.P.and Carrere, H. Effect of lignin-derived and furan compounds found in lignocellulosic hydrolysates on biomethane production. Bioresour Technol 104, 90-99 (2012). https://doi.org/10.1016/j.biortech.2011.10.060

Barcelos, C.A, Maeda, M., Betancur, G.V. and Pereira-Jr, N., The essentialness of delignification on enzymatic hydrolysis of sugar cane bagasse cellulignin for second generation ethanol production. Waste Biomass Valorization, 4, 341-346 (2013). https:// doi.org/10.1007/s12649-012-9137-3

Belal, E.B., Bioethanol production from rice straw residues. Braz J Microbiol, 44(1) (2013). https:// doi.org/10.1590/S1517-83822013000100033

Bellido, C., González-Benito, G., Coca, M., Lucas, S. and García-Cubero, M.T., Influence of aeration on bioethanol production from ozonized wheat straw hydrolysates using Pichia stipitis. Bioresour Technol, 133, 51-58 (2013). https://doi. org/10.1016/j.biortech.2013.01.104

Betancur, G.J.V. and Pereira, J.R.N., Sugar cane bagasse as feedstock for second generation ethanol production: Part II: Hemicellulose hydrolysate fermentability. Elec J Biotechnol, 13, 14-15 (2010).

Buruiana, C.T., Vizireanu, C., Garrote, G. and Parajó, J.C., Optimization of corn stover biorefinery for coproduction of oligomers and second generation bioethanol using non-isothermal autohydrolysis. Ind Crops Prod, 54, 32-39 (2014). https://doi. org/10.1016/j.indcrop.2014.01.003

Camargo, D., Sene, L., Production of ethanol from the hemicellulosic fraction of sunflower meal biomass. Biomass Convers Biorefin, 4, 87-93 (2014). https:// doi.org/10.1007/s13399-013-0096-0

Camargo, D., Sene, L., Variz, D.I.L.S. and Felipe, M.G.A., Xylitol bioproduction in hemicellulosic hydrolysate obtained from sorghum forage biomass. Appl Biochem Biotechnol. 175, 3628-3642 (2015). https://doi.org/10.1007/s12010-015-1531-4

Canilha, L., Carvalho, W., Felipe, M.G.A., Almeida, J.B. and Giuletti, M., Ethanol production from sugarcane bagasse hydrolysate using Pichia stipitis. Appl Biochem Biotechnol, 161, 84-92 (2010). https://doi.org/10.1007/s12010-009-8792-8

Canilha, L., Carvalho, W., Felipe, M.G.A., Silva, J.B.A., Xylitol production from wheat straw hemicellulosic hydrolysate: hydrolysate detoxification and carbon source used for inoculum preparation. Braz J Microbiol, 39, 333-336 (2008). https://doi. org/10.1590/S1517-83822008000200025 
Chaud, L. C. S., Silva, D. D. V. D., Mattos, R. T. D. and Felipe, M. D. G. D. A., Evaluation of oat hull hemicellulosic hydrolysate fermentability employing Pichia stipitis. Braz Arch Biol Technol, 55, 771-777 (2012). https://doi. org/10.1590/S1516-89132012000500017

Cherubini, F., and Stromman, A.H., Chemicals from lignocellulosic biomass: opportunities, perspectives, and potential of biorefinery systems. Biofuels Bioprod Bioref, 5, 548-561 (2011). https:// doi.org/10.1002/bbb.297

Dagnino, E.P., Chamorro, E., Romano, S.D., Felissia, F. and Area, M.C., Optimization of the acid pretreatment of rice hulls to obtain fermentable sugars for bioethanol production. Ind Crops Prod, 42, 363-368 (2013). https://doi.org/10.1016/j. indcrop.2012.06.019

Dien, B.S., Sarath, G., Pederson, J.F., Sattler, S.E., Chen, H., Funnell-Harris DL., Nichols, N.N., Cotta, M.A., Improved sugar conversion and ethanol yield for forage sorghum (Sorghum bicolor 1. Moench) lines with reduced lignin contents. BioEnergy, 2, 153-164 (2009). https://doi.org/10.1007/s12155-009-9041-2

Dussán, K.J., Silva, D.D.V., Moraes, E.J.C., Arruda, P.V. and Felipe, M.G.A., Dilute-acid hydrolysis of cellulose to glucose from sugarcane bagasse. Chem Eng Trans, 38, 433-438 (2009).

Dussán, K.J., Silva, D.D.V., Perez, V.H. and Silva, S.S., Evaluation of oxygen availability on ethanol production from sugarcane bagasse hydrolysate in a batch bioreactor using two strains of xylose-fermenting yeast. Renewable Energy, 87, 703-710 (2016). https://doi.org/10.1016/j. renene.2015.10.065

Ferreira, A.D., Mussatto, S.I., Cadete, R.M., Rosa, C.A. and Silva, S.S., Ethanol production by a new pentose-fermenting yeast strain Scheffersomyces stipitis UFMG-IMH 43.2, isolated from the Brazilian forest. Yeast, 28, 547-554 (2011). https:// doi.org/10.1002/yea.1858

Fu, N., Peiris, P., Markham, J.and Bavor, J., A novel co-culture process with Zymomonas mobilis and Pichia stipitis for efficient ethanol production on glucose/xylose mixtures. Enz Microbial Technol. 45, 210-217 (2009). https://doi.org/10.1016/j. enzmictec.2009.04.006

Gladis, A., Bondesson, P.M., Gaibe, M. and Zacchi G., Influence of different SSF conditions on ethanol production from corn stover at high solids loadings. Energy Sci Eng; 3, 481-489 (2015). https://doi. org/10.1002/ese3.83

Guilherme, A. A., Dantas, P. V. F., Santos, E. S., Fernandes, F. A. N. and Macedo, G. R., Evaluation of composition, characterization and enzymatic hydrolysis of pretreated sugar cane bagasse. Braz J Chem Eng, 32, 23-33 (2015). https://doi. org/10.1590/0104-6632.20150321s00003146
Gutiérrez-Rivera, B., Ortiz-Muñiz, B., GómezRodríguez, J., Cárdenas-Cágal, A., González, J.M.D. and Aguilar-Uscanga, M.G., Bioethanol production from hydrolyzed sugarcane bagasse supplemented with molasses "B" in a mixed yeast culture. Renewable Energy, 74, 299-405 (2014).

Heredia-Olea, E., Pérez-Carrillo, E., Serna-Saldívar, S. O., Effects of different acid hydrolyses on the conversion of sweet sorghum bagasse into C5 and C6 sugars and yeast inhibitors using response surface methodology. Bioresour Technol, 119, 216-223 (2012). https://doi.org/10.1016/j. biortech.2012.05.122

Heredia-Olea, E., Pérez-Carrillo, E., Serna-Saldívar, S. O., Production of ethanol from sweet sorghum bagasse pretreated with different chemical and physical processes and saccharified with fiber degrading enzymes. Bioresour Technol, 134, 386-390 (2013). https://doi.org/10.1016/j. biortech.2013.01.162

Jafari, V., Labafzadeh, S.R., Jeihanipour, A., Karimi, K. and Taherzadeh, M.J., Construction and demolition lignocellulosic wastes to bioethanol. Renewable Energy, 36, 2771-2775 (2011). https:// doi.org/10.1016/j.renene.2011.04.028

Jeevan, P., Nelson, R. and Rena, A.E., Microbial production of xylitol from corn cob hydrolysate using Pichia sp. Adv Environ Biol, 5, 3613-3620 (2011).

Jönsson, L.J., Alriksson, B., Nilvebrant, N.O., Bioconversion of lignocellulose: inhibitors and detoxification. Biotechnol Biofuels. 6, 1-10 (2013). https://doi.org/10.1186/1754-6834-6-16

Kim, M. and Day, D.F., Composition of sugar cane, energy cane, and sweet sorghum suitable for ethanol production at Louisiana sugar mills. J Ind Microbiol Biotechnol 38, 803-807 (2011). https:// doi.org/10.1007/s10295-010-0812-8

Lee, T.Y., Kim, M.D., Kim, K.Y., Park, K., Ryu, Y.W and Seo, J.H., A parametric study on ethanol production from xylose by Pichia stipitis. Biotechnol Bioprocess Eng, 5, 27-31 (2000). https://doi.org/10.1007/BF02932349

Liu, X., Lu, M., Yu, N.A.F and Ji, J., Kinetic model analysis of dilute sulfuric acid-catalyzed hemicellulose hydrolysis in sweet sorghum bagasse for xylose production. Ind Crops Prod, 38, 81-86 (2012). https://doi.org/10.1016/j. indcrop.2012.01.013

Martin, C., Alriksson, B., Sjode, A., Nilvebrant, N.O. and Jonsson, L.J., Dilute sulfuric acid pretreatment of agricultural and agro-industrial residues for ethanol production. Appl Biochem Biotechnol, 137, 339-352 (2007). https://doi.org/10.1007/ s12010-007-9063-1 
Marton, J. M., Felipe, M. G. A., Almeida e Silva, J. B. and Pessoa Junior, A., Evaluation of the activated charcoals and adsorption conditions used in the treatment of sugarcane bagasse hydrolysate for xylitol production. Braz J Chem Eng, 23, 9-21 (2006). https://doi.org/10.1590/S010466322006000100002

May, A., Campanha, M., Silva, A., Coelho, M., Parrella, R.A.C., Schaffert, R.E and Filho, I.A.P., Variedades de sorgo sacarino em diferentes espaçamentos e população de plantas. Rev Bras Milho Sorgo, 11, 278-290 (2012). https://doi.org/10.18512/19806477/rbms.v11n3p278-290

Mehmood, S., Gulfraz, M., Rana, N.F., Ahmad, A., Ahring, B.K., Minhas, N. and Malik, M.F., Ethanol production from Sorghum bicolor using both separate and simultaneous saccharification and fermentation in batch and fed batch systems. Afr J Biotechnol, 8, 2857-2865 (2009).

Nigam JN., Ethanol production from wheat straw hemicellulose hydrolysate by Pichia stipitis. J Biotechnol 87, 17-27 (2001). https://doi. org/10.1016/S0168-1656(00)00385-0

Nigam, J.N., Development of xylose-fermenting yeast Pichia stipitis for ethanol production through adaptation on hardwood hemicellulose acid prehydrolysate. J Appl Microbiol, 90, 208-215 (2001). https://doi.org/10.1046/j.1365-2672.2001.01234.x

Offical Methods of Analysis of AOAC International. 16 th ed. Gaithersburg: Assoc. Off. Anal. Chem (1995).

Oh, Y.H., Eom, I.Y., Joo, J.C., Yu, J.H., Song, B.K., Lee, S.H., Hong, S.H. and Park, S.J., Recent advances in development of biomass pretreatment technologies used in biorefinery for the production of bio-based fuels, chemicals and polymers. Korean J Chem Eng, 32, 1945-1959 (2015). https:// doi.org/10.1007/s11814-015-0191-y

Pérez, J, Muñoz-Dorado, J., Rubia, T.D.l; and Martínez, J., Biodegradation and biological treatments of cellulose, hemicellulose and lignin: an overview. Int Microbiol 5, 53-63 (2002). https:// doi.org/10.1007/s10123-002-0062-3

Ping, Y., Ling, H.Z., Song, G. and Ge, J.P., Xylitol production from non-detoxified corncob hemicellulose acid hydrolysate by Candida tropicalis. Biochem Eng J, 75, 86-91 (2013). https://doi.org/10.1016/j.bej.2013.03.022

Poonsrisawat, A., Phuengjayaem, S., Petsom, A. and Teeradakorn, S., Conversion of sweet sorghum straw to sugars by dilute acid saccharification. Sugar Tech, 15, 322-327 (2013). https://doi. org/10.1007/s12355-013-0235-8

$\mathrm{Pu}, \mathrm{Y} ., \mathrm{Hu}, \mathrm{F}$., Davison, B.H.and Ragauskas, A.J., Assessing the molecular structure basis for biomass recalcitrance during dilute acid and hydrothermal pretreatments. Biotechnol Biofuels, 6, 6-15 (2013). https://doi.org/10.1186/1754-6834-6-15
Qi, W., Zhang, S.P., Xu, Q.L., Ren, Z.W. and Yan, Y.J., Degradation kinetics of xylose and glucose in hydrolysate containing dilute sulfuric acid. Chinese J Process Eng, 8, 1132-1137 (2008).

Rabelo, S.C., Andrade, R.R., Filho, R.M. and Costa, A.C., Alkaline hydrogen peroxide pretreatment, enzymatic hydrolysis and fermentation of sugarcane bagasse to ethanol. Fuel, 136, 349-357 (2014). https://doi.org/10.1016/j.fuel.2014.07.033

Rouhollah, H., Iraj, N., Giti, E. and Sorah, A., Mixed sugar fermentation by Pichia stipitis, Sacharomyces cerevisiae, and an isolated xylose fermenting Kluyveromyces marxianus and their cocultures. Afr J Biotechnol, 6, 1110-1114 (2007).

Saha, B.C., Nichols, N.N., Qureshi, N., Kennedy, G.J., Iten, L.B. and Cotta, M.A., Pilot scale conversion of wheat straw to ethanol via simultaneous saccharification and fermentation. Bioresour Technol, 175, 17-22 (2015). https://doi. org/10.1016/j.biortech.2014.10.060

Sene, L., Arruda, P.V., Oliveira, S.M and Felipe, M.G.A., Evaluation of sorghum straw hemicellulosic hydrolysate for biotechnological production of xylitol by Candida guilliermondii. Braz J Microbiol, 42, 1141-1146 (2011). https:// doi.org/10.1590/S1517-83822011000300036

Silva, D.D.V., Cândido, E,J, Arruda, P.V., Silva, S.S. and Felipe, M.G.A., New cultive medium for bioconversion of $\mathrm{C} 5$ fraction from sugarcane bagasse using rice bran extract. Braz J Microbiol. 45, 1469-1475 (2014). https://doi.org/10.1590/ S1517-83822014000400043

Silva, J.P.A., Carneiro, L.M. and Roberto, I.C., Treatment of rice straw hemicellulosic hydrolysates with advanced oxidative processes: a new and promising detoxification method to improve the bioconversion process. Biotechnol Biofuels, 6, 1-13 (2013). https://doi.org/10.1186/1754-6834-6-23

Silva, J.P.A., Carneiro, L.M., and Roberto, I.C., Assessment of advanced oxidative processes based on heterogeneous catalysis as a detoxification method of rice straw hemicellulose hydrolysate and their effect on ethanol production by Pichia stipitis. Biomass Convers Biorefin, 4, 225-236 (2014). https://doi.org/10.1007/s13399-013-0104-4

Silva, J.P.A., Mussatto, S.I., Roberto, I.C. and Teixeira, J.A., Fermentation medium and oxygen transfer conditions that maximize the xylose conversion to ethanol by Pichia stipitis. Renewable Energy, 37, 259-265 (2012). https://doi.org/10.1016/j. renene.2011.06.032

Silva, N. L. C., Betancur, G. J. V., Vasquez, M. P., de Barros Gomes, E., and Pereira Jr, N., Ethanol production from residual wood chips of cellulose industry: acid pretreatment investigation, hemicellulosic hydrolysate fermentation, and 
remaining solid fraction fermentation by SSF process. Appli Biochem Biotechnol, 163, 928-936 (2011). https://doi.org/10.1007/s12010-010-9096-8

Singh. L.K., Chaudhary, G., Majumder, C.B. and Ghosh, S., Utilization of hemicellulosic fraction of lignocellulosic biomaterial for bioethanol production. Adv Appl Sci Res, 2, 508-521 (2011).

Singhania, R.R., Saini, J.K., Saini, R., Adsul, M., Mathur, A., Gupta, R. and Tuli D.K., Bioethanol production from wheat straw via enzymatic route employing Penicillium janthinellum cellulases. Bioresour Technol, 169, 490-495 (2014). https:// doi.org/10.1016/j.biortech.2014.07.011

Singleton, V.L., Orthofer, R. and Lamuela-Raventos, R. M. Analysis of total phenols and other oxidation substrates and antioxidants by means of FolinCiocalteu reagent. Methods Enzymol, 299, 152-178 (1999). https://doi.org/10.1016/S00766879(99)99017-1

Sluiter, A., Hames, B., Hyman, D., Payne, C., Ruiz, R., Scarlata, C. and Wolfe, J., Determination of total solids in biomass and total dissolved solids in liquid process samples. National Renewable Energy Laboratory, Golden, CO, NREL Technical Report No. NREL/TP-510-42621, 1-6 (2008).

Sluiter, A., Hames, B., Ruiz, R., Scarlata, C., Sluiter, J., Templeton, D., and Crocker, D., Determination of structural carbohydrates and lignin in biomass. Laboratory Analytical Procedure (LAP). NREL, 1617 (2008a).

Sluiter, A., Ruiz, R., Scarlata, C., Sluiter, J. and Templeton, D., Determination of extractives in biomass in biomass. Laboratory Analytical Procedure (LAP). NREL. (2008b).

Stoutenburg, R.M., Perrotta, J., Amidon, T.E. and Nakas, J., Ethanol production from a membrane purified hemicellulosic hydrolysate derived from sugar maple by Pichia stipitis NRRL Y-7124. Biores, 3, 1349-1358 (2008).

Toivola, A., Yarrow, D., Bosch E.V.D., Dijken, J.P.V. and Scheffersi, A.W., Alcoholic fermentation of D-xylose by yeasts. Appl Environ Microbiol., 47, 1221-1223 (1984).

Wang, M., Han, J., Dunn, J.B., Cai, H., Elgowainy, A., Well-to-wheels energy use and greenhouse gas emissions of ethanol from corn, sugarcane and cellulosic biomass for US use. Environ Res Lett, 7, 1-13 (2012). https://doi.org/10.1088/17489326/7/4/045905

Wong, D.W.S., Structure and action mechanism of ligninolytic enzymes. Appl Biochem Biotechnol, 157, 174-209 (2009). https://doi.org/10.1007/ s12010-008-8279-z

Wu, X., Staggenborg, S., Propheter, J.L, Rooney, W.L. and Yu, J., Features of sweet sorghum juice and their performance in ethanol fermentation. Ind Crops Prod, 31, 164-170 (2010). https://doi. org/10.1016/j.indcrop.2009.10.006

Zhang, B.Z, Zhang, S.P., Zhao, S.T., Xu, Q.L and Yan, Y.J., Conversion of sweet sorghum bagasse residue to glucose by dilute acid hydrolysis. Energy Sources, Part A: Recovery, Utilization, and Environmental Effects, 37, (2015). https://doi.org/ $10.1080 / 15567036.2011 .625391$ 